
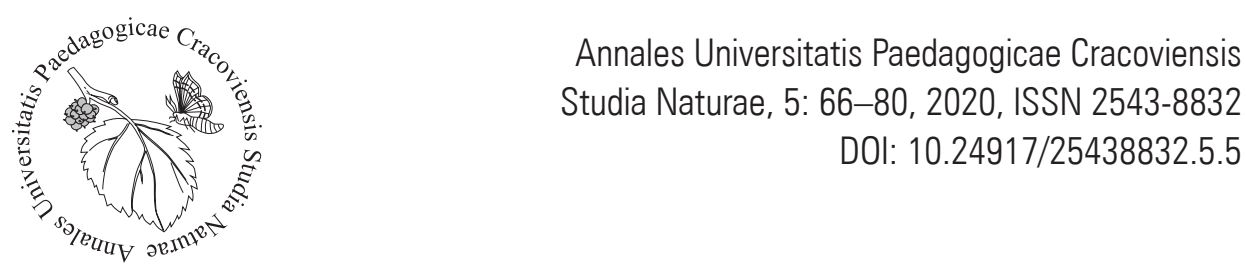

Studia Naturae, 5: 66-80, 2020, ISSN 2543-8832

DOI: $10.24917 / 25438832.5 .5$

Beata Jakubik*, Krzysztof Lewandowski, Aleksandra Biernat

Siedlce University of Natural Sciences and Humanities, Institute of Biological Sciences, B. Prusa 14 St., 08-110 Siedlce, Poland; *beata.jakubik@uph.edu.pl

\title{
Changes of malacofauna in a small lowland river in eastern Poland
}

\section{Introduction}

Molluscs are an important component of the biodiversity of freshwater invertebrate fauna (e.g. Jurkiewicz-Karnkowska, 2004; Królak, Korycińska, 2008; Piechocki, 2008). The malacofauna of large Polish rivers is well recognised (e.g. Piechocki, 1996; Jurkiewicz-Karnkowska, 2004; Lewandowski, 2004; Jurkiewicz-Karnkowska, Karnkowski, 2013; Piechocki, Szlauer-Łukaszewska, 2013; Lewin, 2014). Studies on the occurrence of molluscs in small lowland rivers in our climate zone, despite their long tradition, are fragmentary (e.g. Piechocki, 1969, 1972; Kasprzak, 1975; Kołodziejczyk, 1994; Jakubik, 2003, 2008; Jurkiewicz-Karnkowska, 2019). Areas less recognised for malacofauna include the Siedlce Upland - part of the South Podlasie Lowland (Kondracki, 2002).

Malacofauna of small watercourses in the Siedlce Upland is poorly understood. Some remarks on species present in the region were provided by Królak (1998), who described the results of her studies on the content of heavy metals in molluscs of the Siedlce Upland. Apart from papers by Jakubik (2003), Korycińska (2002) and Jurkiewicz-Karnkowska $(2016,2019)$, no detailed data on molluscs from this region can be found.

The Muchawka River is a left-bank tributary of the Liwiec River - the main river of the Siedlce Upland. Therefore, species composition of molluscs in the former may markedly affect taxonomic diversity in the latter. The Muchawka River drains mostly agricultural grounds and, thus, is not significantly polluted by domestic and/or industrial wastewaters. Until 1999, data about the river were limited to general faunistic and floristic characteristics and to annual assessment of water quality performed by the Environmental Protection Inspectorate based on physical, chemical and biological parameters (Bakiera et al., 1993). That is why detailed faunistic studies on molluscs in the river were undertaken in the years 1999-2000 (Jakubik, 2003). Sixteen years later, the assessment of taxonomic composition of molluscs in the Muchawka River, in relation to certain environmental factors, was repeated. 


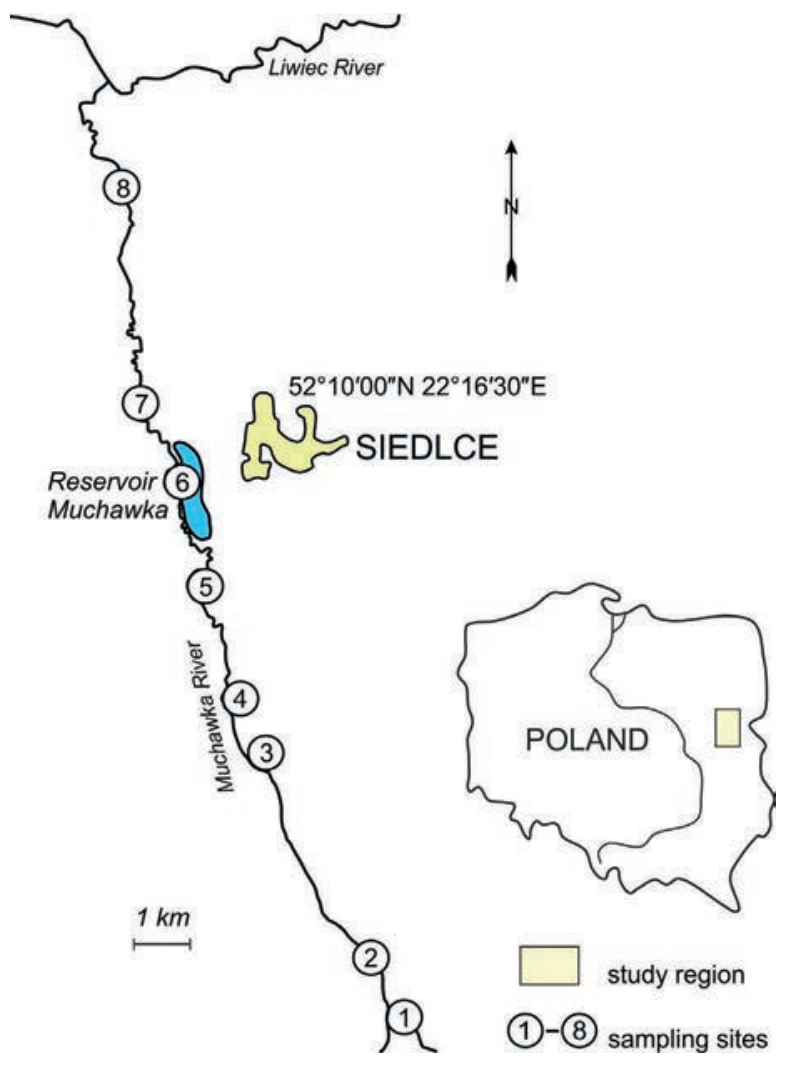

Fig.1. Location of the sampling sites (Jakubik, 2003)

Material and methods

Study area

Studies were carried out in the Muchawka River $\left(52^{\circ} 12^{\prime} 35^{\prime \prime} \mathrm{N}, 22^{\circ} 13^{\prime} 10^{\prime \prime} \mathrm{E}\right)$ - a leftbank tributary of the Liwiec River. It springs about $2 \mathrm{~km}$ south of Daćbogi village and flows across the Siedlce Upland. The river is about $30 \mathrm{~km}$ long and its catchment area is $292 \mathrm{~km}^{2}$.

The river forms a valley overgrown by periodically flooded meadows. The Muchawka River valley is floristically rich, especially in vascular plants. There are about 400 species of vascular plants dominated by the families Asteraceae, Poaceae and Fabaceae from meadow, aquatic and rush communities (Kot, Dombrowski, 2001). Waters of the Muchawka River feed a recreational dam reservoir in Siedlce. Eight sampling sites, the same as in Jakubik (2003), were selected along the course of the Muchawka River (Fig. 1,2). Characteristics of the sampling sites are given in table 1. 


\begin{tabular}{|c|c|c|c|c|c|}
\hline \multirow{2}{*}{$\begin{array}{l}\text { No. } \\
\text { site }\end{array}$} & \multicolumn{2}{|c|}{ Type } & \multirow{2}{*}{$\begin{array}{l}\text { Width the } \\
\text { river }[\mathrm{m}]\end{array}$} & \multirow{2}{*}{$\begin{array}{l}\text { Sampling } \\
\text { depth }[\mathrm{cm}]\end{array}$} & \multirow[t]{2}{*}{ Vegetation } \\
\hline & bottom & river bank & & & \\
\hline 1 & muddy & $\begin{array}{l}\text { high, enforced } \\
\text { with wooden } \\
\text { stakes }\end{array}$ & $2-3$ & 50 & $\begin{array}{l}\text { Acorus calamus L., Elodea canadensis } \\
\text { Michx, Phragmites australis (Cav.) Trin. } \\
\text { ex Steud, Sparganium ramosum Curtis }\end{array}$ \\
\hline 2 & sandy-stony & natural & 2 & 20 & Sparganium ramosum Curtis \\
\hline 3 & stony-muddy & & 3 & 20 & $\begin{array}{l}\text { Elodea canadensis Michx, Juncus effusus } \\
\text { L., Nuphar lutea L. Sibth \& Sm, Sagittaria } \\
\text { sagittifolia L. }\end{array}$ \\
\hline 4 & sandy-stony & & 5 & 30 & $\begin{array}{l}\text { Elodea canadensis Michx, Nuphar lutea } \\
\text { L. Sibth \& Sm, Phragmites australis (Cav.) } \\
\text { Trin.ex Steud Sagittaria sagittifolia L. }\end{array}$ \\
\hline 5 & Sancy-siony & $\begin{array}{c}\text { natural, gentle } \\
\text { slope }\end{array}$ & 6 & 80 & $\begin{array}{l}\text { Elodea canadensis Michx, Nuphar lutea } \\
\text { L. Sibth \& Sm, Sagittaria sagittifolia L., } \\
\text { Sparganium ramosum Curtis }\end{array}$ \\
\hline 6 & & & 6 & 30 & $\begin{array}{l}\text { Elodea canadensis Michx, Nuphar lutea L. } \\
\text { Sibth \& Sm, Sagittaria sagittifolia L. }\end{array}$ \\
\hline 7 & sandy-muddy & & 6 & 30 & $\begin{array}{l}\text { Nuphar lutea L. Sibth \& Sm, Sagittaria } \\
\text { sagittifolia L., Sparganium ramosum } \\
\text { Curtis, Typha latifolia L. }\end{array}$ \\
\hline 8 & muddy & $\begin{array}{l}\text { natural, gently } \\
\text { sloping, steep } \\
\text { in some places }\end{array}$ & 8 & 30 & $\begin{array}{l}\text { Nuphar lutea L. Sibth \& Sm, Phragmites } \\
\text { australis (Cav.) Trin.ex Steud, Sagittaria } \\
\text { sagittifolia L., Typha latifolia L. }\end{array}$ \\
\hline
\end{tabular}

\section{Methods}

Water and molluscs were sampled in late spring (May to June) and in summer (July to the middle of September) 2016 in triplicate from every sampling site. Water for chemical analyses was collected in polyethylene containers and preserved with $2-3 \mathrm{~cm}^{3}$ of chloroform per $1 \mathrm{dm}^{3}$ of water (Hermanowicz et al., 1999). Dissolved oxygen (measured with the oxygen probe EOT 196), temperature and electrolytic conductivity of water (conductivity meter CC-317) were determined in the field at each sampling site. Water $\mathrm{pH}$ (digital pH-meter CP-215), water hardness and concentrations of ammonium-nitrogen, nitrate-nitrogen, phosphates (field photometer LF-205) and chlorides (with the argentometric method as in Hermanowicz et al., 1999) were determined in the laboratory.

Based on physical and chemical parameters, water quality of the Muchawka River was estimated and compared with earlier data (Tab. 2).

Molluscs were sampled with a 20 -cm-wide grab sampler (Jakubik, 2003). The sample was material collected from an area of one square meter. Bivalves of the family 


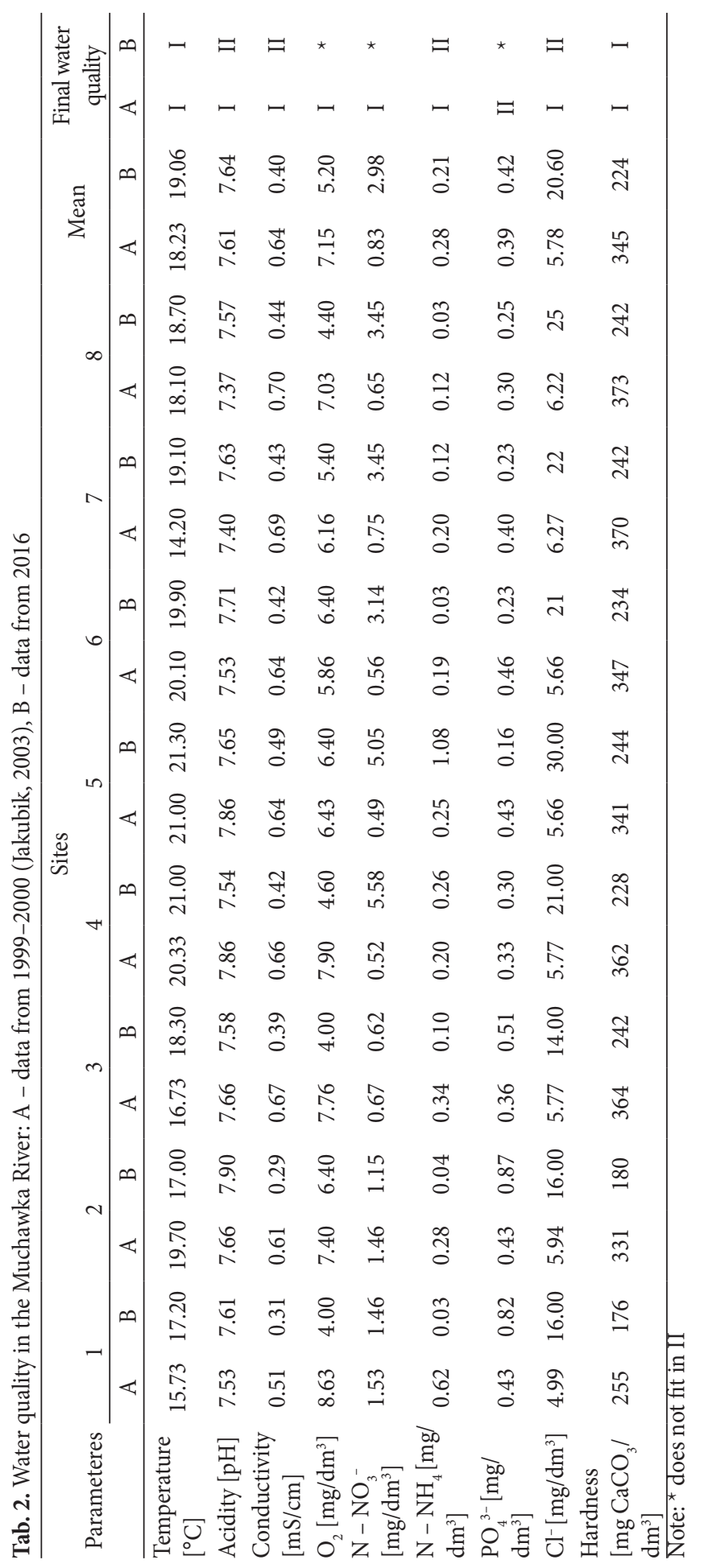




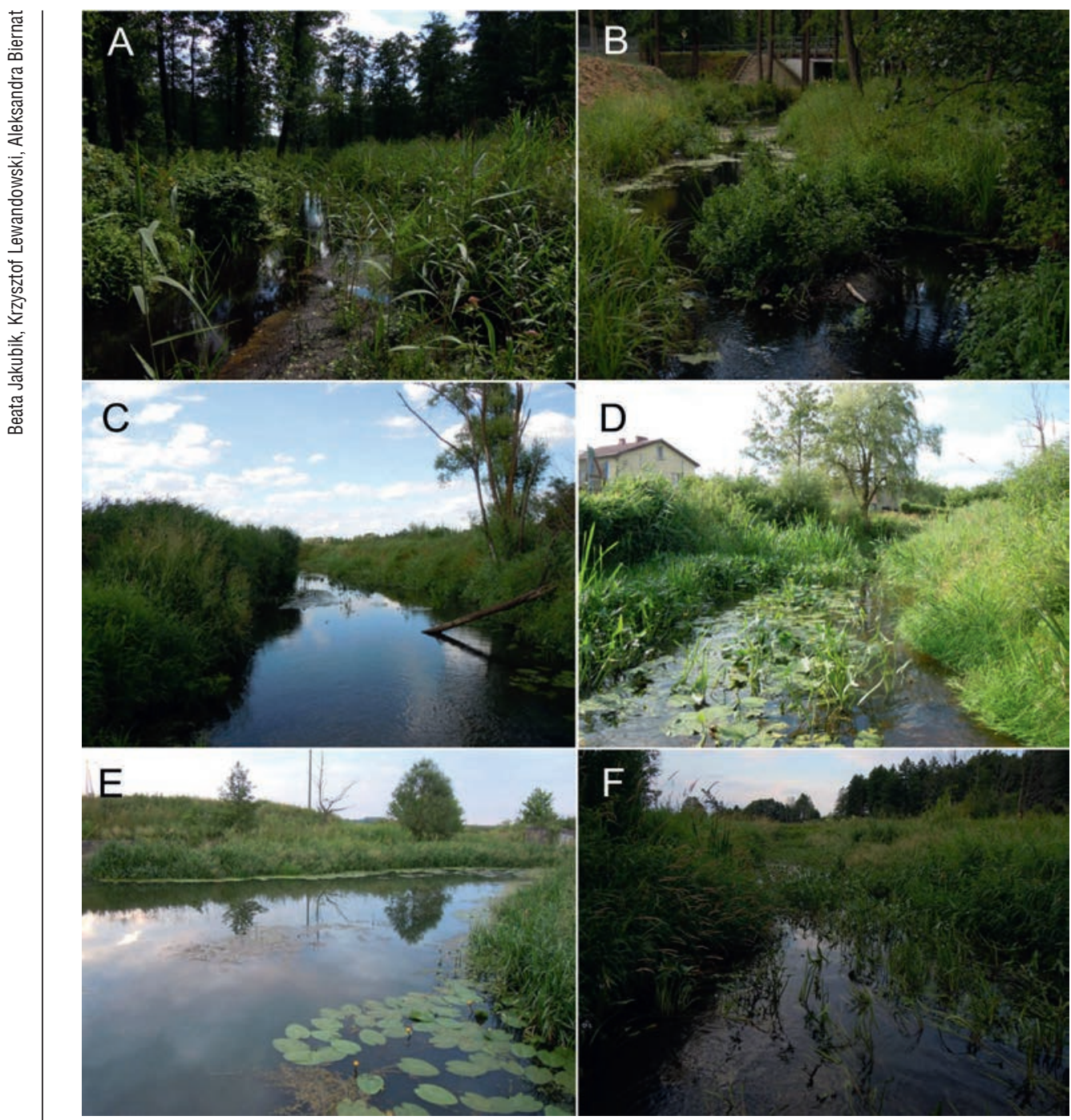

Fig. 2. A, B - sites (1-2) in the upper section of the river; C, D - sites (4-5) in the middle stretch; E, F sites $(7-8)$ in the lower river section (Photo. K. Lewandowski)

Unionidae were determined to the species level and then released back into the water. In the field, collected material was washed on a sieve of $0.5 \mathrm{~mm}$ mesh. In the laboratory, molluscs were preserved in $70 \%$ ethanol. Molluscs were identified to the species level based on their morphological and anatomical features according to Piechocki and Dyduch-Falniowska (1993), Jackiewicz (2000), Piechocki and Wawrzyniak-Wydrowska (2016). The species nomenclature follows Glöer (2002). 
The following parameters were calculated (Górny, Grüm, 1981): (1) the total number of species (S); (2) density - expressed as the number of individuals per square metre; (3) domination according to the formula $\mathrm{D}=100 \times \mathrm{n}_{\mathrm{i}} / \mathrm{N}$ where $\mathrm{n}_{\mathrm{i}}$ is the number of individuals of the $\mathrm{i}$-th species and $\mathrm{N}$ is the number of individuals of all species; the value of the domination, $\mathrm{D}$, was divided into 5 classes: eudominants $>10.0 \%$, dominants $5.1-10.0 \%$, subdominants $2.1-5.0 \%$, recedents $1.1-2.0 \%$ and subrecedents $\leq 1.0 \%$ of the sample; (4) the Shannon-Wiener index (H') (Hauer, Lamberti, 2007): $\mathrm{H}^{\prime}=-S \mathrm{P}_{\mathrm{i}} \ln$ $P_{i}$ where $P_{i}=N_{i} / N$ - the share of individuals of the $i$-th species.

The significance of differences between the number of species and densities at particular sites visited in 1999-2000 and in 2016 were evaluated with the Tukey one-way ANOVA test (Statistica v. 10). The compared parameters had a normal distribution.

\section{Results}

Temperature and water hardness did not exceed standards established for the first class of water quality (Rozporzadzenie Ministra Środowiska..., 2016). Water pH, electrolytic conductivity and concentrations of ammonium-nitrogen and chlorides corresponded to the second class of water quality. Only the concentrations of nitrate-nitrogen, phosphates and oxygen were higher than those typical for the second class of water quality (Tab. 2). Because of agricultural management of surrounding lands, the main source of phosphates delivered to the river is surface runoff from fields and meadows. Studies on malacofauna of the Muchawka River carried out in the years 1999-2000 revealed the presence of 12 mollusc species: five species of bivalves and seven species of snails (Tab. 3).

Tab. 3. Species composition of molluscs in the Muchawka River 1999-2000 (Jakubik, 2003) and the present study

\begin{tabular}{clcc}
\hline No. & \multicolumn{1}{c}{ Species } & 1999-2000 & 2016 \\
\hline 1. & Anisus vortex Linnaeus & & $\times$ \\
2. & Anodonta anatina Linnaeus & $\times$ & $\times$ \\
3. & A. cygnea Linnaeus & $\times$ & $\times$ \\
4. & Bathyomphalus contortus Linnaeus & $\times$ & $\times$ \\
5. & Bithynia tentaculata Linnaeus & $\times$ & $\times$ \\
6. & Lymnaea stagnalis Linnaeus & & $\times$ \\
7. & Physa acuta Draparnaud & $\times$ & $\times$ \\
8. & P. fontinalis Linnaeus & & $\times$ \\
9. & Planorbarius corneus Linnaeus & &
\end{tabular}




\begin{tabular}{|c|c|c|c|}
\hline 11. & P. planorbis Linnaeus & $x$ & $x$ \\
\hline 12. & Pisidium amnicum O.F.Müller & $x$ & $x$ \\
\hline 13. & P. casertanum Poli & & $x$ \\
\hline 14. & P. henslowanum Sheppard & & $x$ \\
\hline 15. & P. nitidum Jenyns & & $x$ \\
\hline 16. & P. subtruncatum Malm & & $x$ \\
\hline 17. & Radix ampla Hartmann & $x$ & \\
\hline 18. & R. auricularia Linnaeus & $x$ & \\
\hline 19. & Sphaerium corneum Linnaeus & & $x$ \\
\hline 20. & S. rivicola Lamarck & $x$ & \\
\hline 21. & Unio crassus Philipsson & & $x$ \\
\hline 22. & U. pictorum Linnaeus & $x$ & \\
\hline 23. & Valvata cristata O.F.Müller & & $x$ \\
\hline 24. & Viviparus contectus Millet & $x$ & $x$ \\
\hline Total & & 12 & 19 \\
\hline
\end{tabular}

In 2016, there were 19 species of molluscs in the river including 11 species of snails and 8 species of bivalves. Seven species of molluscs (5 species of snails and 2 species of bivalves) were recorded in both periods. Species invariably present in the river since 1999 were: Anodonta anatina, Bithynia tentaculata, Lymnaea stagnalis, Physa fontinalis, Pisidium amnicum, Planorbis planorbis, Viviparus contectus. Malacofauna showed both qualitative and quantitative diversity. In total, 390 individuals of molluscs were noted at all sites. Pisidium casertanum - one of eudominants - was present only at the last two sites (with densities of 153 individual $\times \mathrm{m}^{-2}$ and 15 individual $\times \mathrm{m}^{-2}$, respectively) and constituted $43.1 \%$ of all molluscs (Tab. 4).

Tab. 4. Density (individual $\times \mathrm{m}^{-2}$ ) and dominance [D\%] of the molluscs at the sampling sites in the Muchawka River (2016)

\begin{tabular}{|c|c|c|c|c|c|c|c|c|c|c|}
\hline \multirow{2}{*}{ Species } & \multicolumn{8}{|c|}{ Sites } & \multirow{2}{*}{$\mathrm{N}$} & \multirow{2}{*}{$\mathrm{D}$} \\
\hline & 1 & 2 & 3 & 4 & 5 & 6 & 7 & 8 & & \\
\hline Anisus vortex & & & & & & & & 1 & 1 & 0.3 \\
\hline Anodonta anatina & & & & & & 1 & & & 1 & 0.3 \\
\hline Bathyomphalus contortus & 2 & 9 & & & & & & & 11 & 2.8 \\
\hline Bithynia tentaculata & 2 & & 12 & 2 & & 1 & & 4 & 21 & 5.4 \\
\hline Lymnaea stagnalis & & & 3 & & & & & & 3 & 0.8 \\
\hline Physa acuta & & & & & & 2 & & & 2 & 0.5 \\
\hline P. fontinalis & & & 8 & & & & & & 8 & 2.0 \\
\hline Pisidium amnicum & & & 9 & & & 5 & & 4 & 18 & 4.6 \\
\hline P. casertanum & & & & & & & 153 & 15 & 168 & 43.1 \\
\hline P. henslowanum & & & & & & 1 & & & 1 & 0.3 \\
\hline
\end{tabular}




\begin{tabular}{|c|c|c|c|c|c|c|c|c|c|c|}
\hline P. nitidum & 9 & & & & & & & & 9 & 2.3 \\
\hline P. subtruncatum & 75 & 12 & & & 2 & & & & 89 & 22.8 \\
\hline Planorbarius corneus & 1 & 2 & 1 & & & & 1 & & 5 & 1.3 \\
\hline Planorbis carinatus & & 2 & & & & & & & 2 & 0.5 \\
\hline P. planorbis & & & 2 & & & & & & 2 & 0.5 \\
\hline Sphaerium corneum & & & 29 & & 1 & 1 & 5 & 4 & 40 & 10.2 \\
\hline Unio crassus & & & 2 & & & & & & 2 & 0.5 \\
\hline Valvata cristata & 1 & & & & & & & & 1 & 0.3 \\
\hline Viviparus contectus & & & 6 & & & & & & 6 & 1.5 \\
\hline Total & 90 & 25 & 72 & 2 & 3 & 11 & 159 & 28 & 390.0 & 100.0 \\
\hline Number of species & 6 & 4 & 9 & 1 & 2 & 6 & 3 & 5 & - & - \\
\hline
\end{tabular}
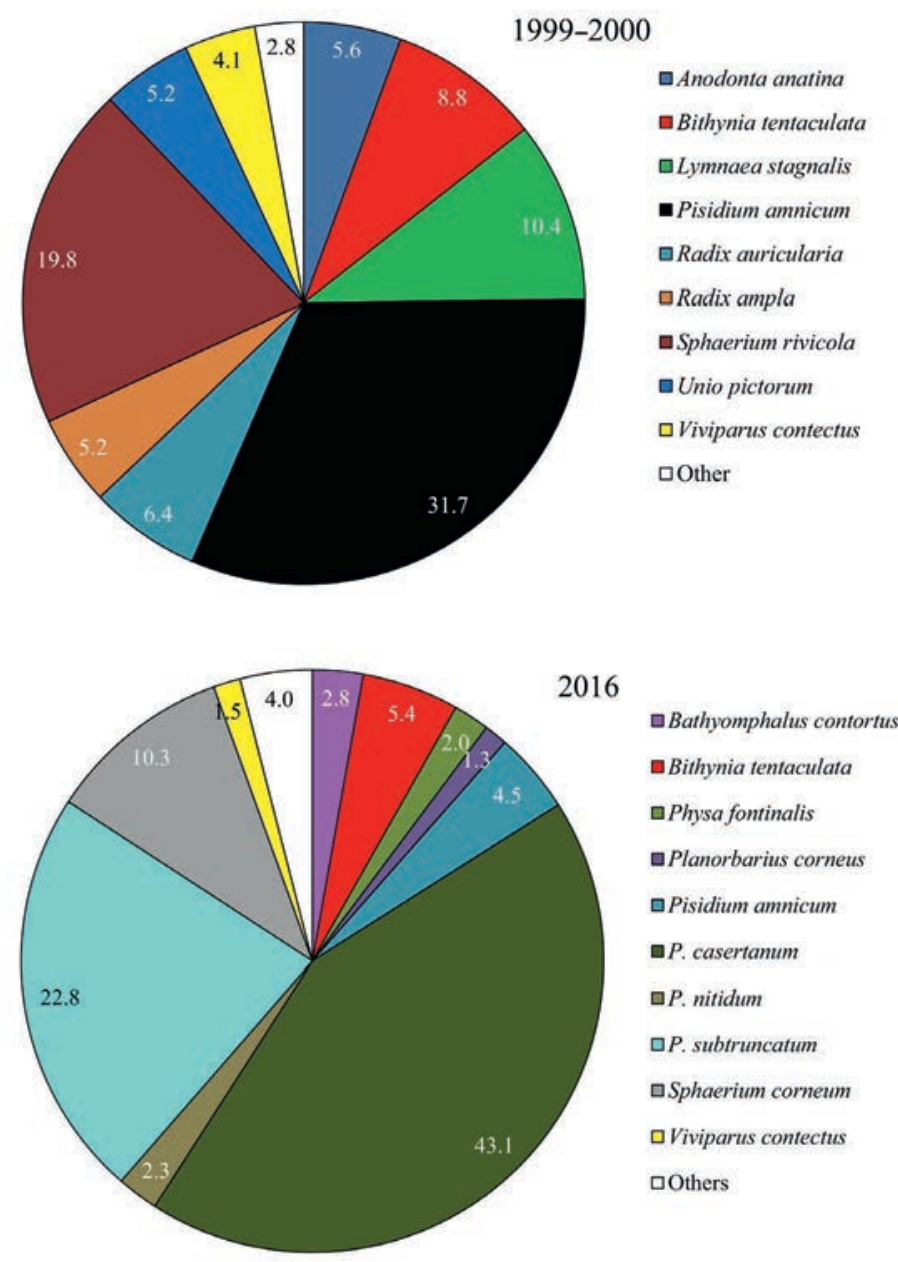

Fig. 3. Comparison of the domination [D\%] of molluscs in the Muchawka River between 1999-2000 (Jakubik, 2003) and 2016 


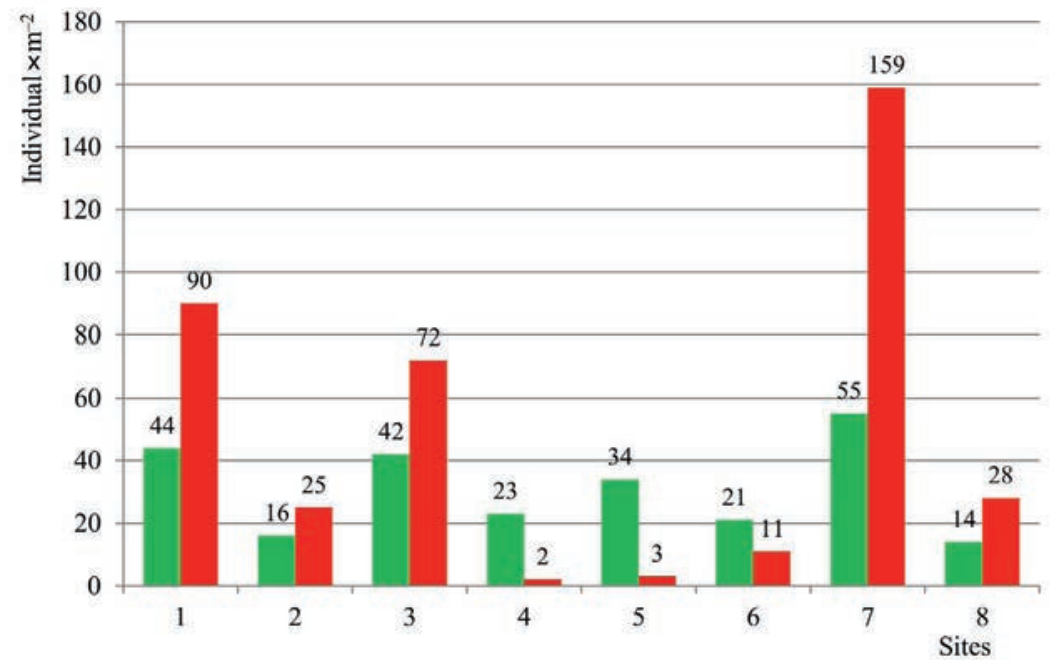

Fig. 4. Comparison of the density (individual $\times \mathrm{m}^{-2}$ ) of molluscs in the Muchawka River between 19992000 (Jakubik, 2003) - green and 2016 - red

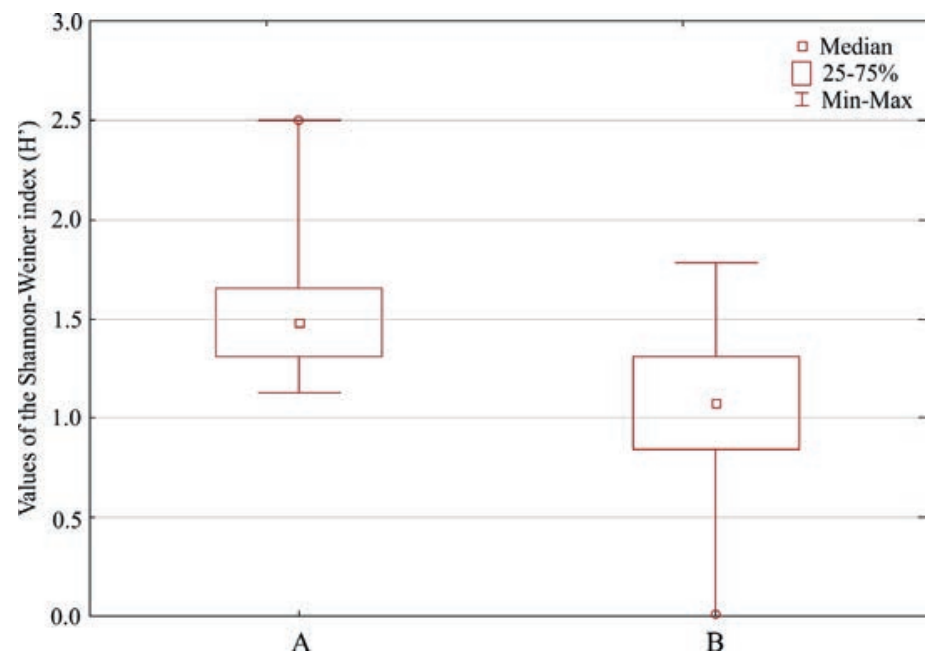

Fig. 5. Comparison of Shannon-Wiener indices $H^{\prime}$ of the molluscs in the Muchawka River between 1999-2000 - (A) (Jakubik, 2003) and 2016 - (B)

Two other species of bivalves of the family Sphaeriidae identified were also eudominants - Pisidium subtruncatum (22.8\%) and Sphaerium corneum (10.3\%) (Fig. 3).

Bivalves of the family Sphaeriidae constituted as many as $83.3 \%$ of all collected molluscs and, together with other bivalves (Unio crassus and Anodonta anatina), comprised $84.1 \%$. Snails were mostly represented by the dominant Bithynia tentaculata (5.4\% of all molluscs) and by subdominant Bathyomphalus contortus (2.8\%). 
Out of eight sites analysed, Sphaerium corneum and the snail Bithynia tentaculata were recorded in five sites. Most of the noted species were present in small densities in single sites. The highest number of mollusc species (9) was found at site 3 and the lowest numbers of species (1-2) were noted at sites within the city limits of Siedlce (sites 4 and 5). Noteworthy was the presence of a protected species, Unio crassus, at a density of 2 individual $\times \mathrm{m}^{-2}$ in site 3 . Apart from living molluscs, the empty shells of other species, such as Valvata piscinalis Müll., Radix balthica L. and Acroloxus lacustris L., were recorded.

Densities of molluscs in the year 2016 were markedly higher compared to those in the years 1999-2000 (Fig. 4). Significant differences were found in sites in the upper course of the river (sites 1,2 and 3) and in sites (7 and 8) near its outlet (Tukey test, $\mathrm{p}<0.05$ ). The Shannon-Wiener index was lower in the year 2016 (Fig. 5).

\section{Discussion}

During the sixteen-year period since the first malacological analysis, the number of mollusc species in the Muchawka River increased from 12 to 19 and was comparable with that in the Skierniewka River (21 species) (Jurkiewicz-Karnkowska, 1989). The number of taxa was, however, lower than that found in the rivers Grabia and Pasłęka (Piechocki, 1969, 1972), Krutynia (Lewandowski, 1996; Jakubik et al., 2014) and Raba, Łubrzanka, Łośna, Biała Nida, Czarna Nida (Piechocki, 1981), Koprzywianka (Piechocki, 1987), Szeszupa (Lewandowski, 1990) and Wieprz (Piechocki, Łuczak, 1989; Piechocki, 1992). In each of the described habitats about 40 species of molluscs were noted.

Out of 19 species of molluscs found in the Muchawka River, 11 species were snails. The number is comparable with the 12 snail species recorded by Korycińska (2002) in the Liwiec River - the recipient of waters of the Muchawka. Later studies of molluscs carried out in the years 2013-2015 showed 26 species in the Liwiec River (Jurkiewicz-Karnkowska 2016, 2019). In the Muchawka River, among the taxa found by Jurkiewicz-Karnkowska in 2016, were noted all species with the exception of Pisidium carinatus and Bathyomphalus contortus.

Grużewski (2000) noted as many as 25 mollusc species including 15 species of snails and 10 species of bivalves in the Pęza River (right-bank tributary of the middle Narew River) which is much smaller than the Muchawka River. Studies from the same author (1996) in the Kamionka River in the Wigry National Park revealed 13 species of molluscs (10 of which were bivalves) - a number similar to that recorded in the Muchawka River in the first study period.

Malacofauna of the Muchawka River was dominated by bivalves of the genera Pisidium and Sphaerium - Pisidium amnicum, Sphaerium rivicola, in the first study pe- 
riod and by Pisidium casertanum and P. subtruncatum in 2016. This phenomenon was confirmed by studies on molluscs by Jurkiewicz-Karnkowska $(2016,2019)$ who found a high frequency of bivalves of both genera in the middle stretch of the Liwiec River, i.e. near the inlet of the Muchawka River. According to Piechocki and Dyduch-Falniowska (1993), these bivalves mainly inhabit lowland rivers and prefer sandy or sandy-muddy largely overgrown substrata and clean or only slightly polluted water (Stadničenko, 1984). Pisidium amnicum is particularly sensitive to water pollution by domestic and industrial wastewaters and does not tolerate intensive eutrophication. The presence of bivalves of the family Unionidae in waters of the Muchawka River was evidence of high water quality, confirmed by physical and chemical analyses in the first study period. Unio pictorum was found in the years 1999-2000 at four sites $(1,2,7$ and 8$)$ of the upper and outlet section of the river (Jakubik, 2003). In view of drastically decreasing numbers of Unionids in lakes and rivers of Poland, the presence of Anodonta anatina, Unio pictorum, U. tumidus, U. crassus (Królak, Korycińska, 2001) in the Liwiec River in the years 1996-1997 is noteworthy. In 2016, the situation for protected species changed, which might be associated with worsening water quality. Increased concentrations of nitrates and phosphates originated from agricultural management of the river drainage basin. Anodonta cygnea, Sphaerium rivicola and Unio pictorum disappeared from the river, while another protected species, Unio crassus, was noted. Studies by Jurkiewicz-Karnkowska $(2016,2019)$ also showed a lack of Anodonta cygnea and Unio pictorum in the middle stretch of the Liwiec River. Of particular importance was the presence of Unio crassus - a species whose occurrence in Poland's waters regularly diminishes due to proceeding eutrophication and degradation of river valleys (Abraszewska-Kowalczyk, 2002; Zając, 2004).

Regarding snails in the Muchawka River, a remarkable share were Bithynia tentaculata, while in the previous study period it was Lymnaea stagnalis. A similar change was reported by Jurkiewicz-Karnkowska $(2016,2019)$ for malacofauna of the Liwiec River. Both species prefer sandy-muddy substrates with some stones, which is characteristic of lowland rivers (Jackiewicz, 2000; Lewin, 2014).

The Shannon-Wiener index for data from 2016 was lower than in the years 19992000. The index increases with increasing number of species in a given community and with the evenness of their densities (Głowaciński, 1996). Despite an increased number of species in 2016, their densities were quite variable - from 2 individual $\times$ $\mathrm{m}^{-2}$ in the middle course of the river to 159 individuals $\times \mathrm{m}^{-2}$ in the outlet.

Malacofauna of the Muchawka River reflects the natural character of a watercourse like this small lowland river (Wiśniewski et al., 1985; Jurkiewicz-Karnkowska, 1989, 2016; Raczyńska, 1999; Grużewski, 2000; Jakubik, 2008; Lewin, 2014). The present study is part of a larger project, which is scheduled to end in 2021. 


\section{Acknowledgements}

The authors wish to express their gratitude to Ewa Jurkiewicz-Karnkowska for help in determining bivalves of the genus Pisidium, to Elżbieta Biardzka for help in chemical analyses and to Lech Kufel for translating this text. We are very grateful to the anonymous reviewers for their valuable comments which help us to improve manuscript.

Conflict of interest

The author declares no conflict of interest related to this article.

\section{References}

Abraszewska-Kowalczyk, A. (2002). Unionid bivalves of the Pilica River catchment area. Folia Malacologica, 10, 99-173. http://dx.doi.org/10.12657/folmal.010.011

Bakiera, A., Głowacki, Z., Kot, H. (1993). Inwentaryzacja i waloryzacja przyrodnicza oraz wytyczne do planu szczegółowego zagospodarowania strefy ekologicznej „Dolina Muchawki” w granicach miasta Siedlce. Maszynopis (dane zaczerpnięte z Urzędu Miasta Siedlce) (inventory and environmental evaluation as well as guidelines for the detailed development plan of the ecological zone "Dolina Muchawki" within the city limits of Siedlce. Typescript (data taken from the Siedlce City Hall)).[In Polish]

Glöer, P. (2002). Die Süßwassergastropoden Nord- und Mitteleuropas: Bestimmungsschüssel, Lebensweise, Verbreitung. Hackenheim: ConchBooks. [In German]

Głowaciński, Z. (1996). Różnorodność gatunkowa - jej interpretacja i obliczanie. W: Różnorodność biologiczna: pojęcia, oceny, zagadnienia ochrony i kształtowania (Species diversity - its interpretation and calculation. In: Biodiversity: concepts, assessments, protection and shaping issues). Zeszyty Naukowe Komitetu „Człowiek i Środowisko”, 15, 57-70. [In Polish]

Górny, M., Grüm, L. (1981). Metody stosowane w zoologii gleby (Methods used in soilzoology). Warszawa: Państwowe Wydawnictwo Naukowe. [In Polish]

Grużewski, M. (1996). Mięczaki rzeki Kamionki w Wigierskim Parku Narodowym (Molluscs of the Kamionka River in the Wigry National Park). XII Krajowe Seminarium Malakologiczne. Łódź. Materiały zjazdowe.[In Polish]

Grużewski, M. (2000). Freshwater molluscs of the Pęza River, a tributary of the Narew River (NE Poland). Acta Universitatis Lodziensis, Folia Limnologica, 7, 163-172.

Hauer, F.R., Lamberti, G.A. (2007). Methods in stream ecology. Academic Press, Elsevier.

Hermanowicz,W., Dożańska, W., Dojlido, J., Koziorowski, B., Zerbe, J. (1999). Fizyczno-chemiczne badanie wody i ścieków (Physico-chemical testing of water and sewage). Warszawa: Wydawnictwo Arkady. [In Polish]

Jackiewicz, M. (2000). Błotniarki Europy (Gastropoda, Pulmonata, Lymnaeidae) (Europa’s Mudmen (Gastropoda, Pulmonata, Lymnaeidae)). Poznań: Wydawnictwo Kontekst. [In Polish]

Jakubik, B. (2003). Molluscs (Mollusca) of the River Muchawka (South Podlasie Lowland, Siedlce Plateau, Poland). Fragmenta Faunistica, 46, 239-247.

Jakubik, B. (2008). Molluscs (Mollusca) in selected small rivers of the Mazovian Lowland. Annales Universitatis Mariae Curie-Skłodowska Lublin-Polonia. Sectio C, 63(2), 45-51.

Jakubik, B., Koperski, P., Lewandowski, K. (2014). Diversity of mollusca in lowland river-lake system: lentic versus lotic patches. Polish Journal of Ecology, 62, 335-348.

Jurkiewicz-Karnkowska, E. (1989). Occurrence of molluscs in the littoral zone of the Zegrzyński Reservoir and in the pre mouth zones of supplying rivers. Ekologia Polska, 37(3-4), 319-336.

Jurkiewicz-Karnkowska, E. (2004). Malacocoenoses of large lowland dam reservoirs of the Vistula River basin and selected aspects of their function. Folia Malacologica, 12, 1-56. http://dx.doi.org/10.12657/ folmal.012.001 
Jurkiewicz-Karnkowska, E. (2016). Longitudinal pattern of mollusc assemblages within a medium-sized lowland river: Liwiec (East Poland). Folia Malacologica, 24, 209-222. http://dx.doi.org/10.12657/folmal.024.018

Jurkiewicz-Karnkowska, E. (2019). Comparative diversity of molluscan fauna of different aquatic habitat types: the Liwiec river catchment (East Poland). Folia Malacologica, 27,179-192. https://doi. org/10.12657/folmal.027.016

Jurkiewicz-Karnkowska, E., Karnkowski, P. (2013). GIS analysis reveals the high diversity and conservation value of mollusc assemblages in the floodplain wetlands of the lower Bug River (East Poland). Aquatic Conservation: Marine and Freshwater Ecosystem, 23, 952-963. https://doi.org/10.1002/aqc.2351

Kasprzak, K. (1975). Zgrupowania małżów z rodzaju Pisidium sensulato (Bivalvia) w różnych typach zbiorników wodnych (Groups of clams of the genus Pisidium sensulato (Bivalvia) in different types of water reservoirs). Fragmenta Faunistica, 20, 131-142.

Kołodziejczyk, A. (1994). Mięczaki słodkowodne Suwalskiego Parku Krajobrazowego (Freshwater mollusks of the Suwałki Landscape Park). Zeszyty Naukowe Komitetu „Człowiek i Środowisko”, 7, 243265. [In Polish]

Kondracki, J. (2002). Geografia regionalna Polski (Regional geography of Poland). Warszawa: Wydawnictwo Naukowe PWN. [In Polish]

Korycińska, M. (2002). Molluscs of the Liwiec River (South Podlasie and Middle Mazovian lowlands). Folia Malacologica, 10, 17-23. http://dx.doi.org/10.12657/folmal.010.003

Kot, H., Dombrowski, A. (2001). Strategia ochrony fauny na Nizinie Mazowieckiej (Strategy for conservation of fauna in the Mazovian Lowland). Siedlce: Mazowieckie Towarzystwo Ochrony Fauny. [In Polish]

Królak, E. (1998). Concentration of heavy metals in the snails Lymnaea (Radix) peregra (O.F. Müll) and Lymnaea stagnalis (L.) occurring in rivers near Siedlce town. Polish Archives Hydrobiology, 45(4), 553-563.

Królak, E., Korycińska, M. (2001). Wybrane grupy makrobezkręgowców rzeki Liwiec i jej dopływów (Selected groups of macroinvertebrates in the Liwiec River and its tributaries). In: H. Kot, A. Dombrowski (eds.), Strategy for conservation of fauna in the Mazovian Lowland. p. 147-158. Siedlce: Mazowieckie Towarzystwo Ochrony Fauny.

Królak, E., Korycińska, M. (2008). Taxonomic composition of macroinvertebrates in the Liwiec River and its tributaries (Central and Eastern Poland) on the basis of chosen physical and chemical parameters of water and season. Polish Journal of Environmental Studies, 17, 39-50.

Lewandowski, K. (1990). Unionidae of Szeszupa River and of the lakes along its course in Suwalski Landscape Park. Ekologia Polska, 38, 271-278.

Lewandowski, K. (1996). Bentos rzeczno-jeziorny stref przejściowych systemu rzeki Krutyni (Pojezierze Mazurskie). W: Funkcjonowanie systemów rzeczno-jeziornych $w$ krajobrazie pojeziernym: rzeka Krutynia (Pojezierze Mazurskie). In: Functioning of river-lake systems in the lake landscape: the Krutynia river (Masurian Lake District). Zeszyty Naukowe Komitetu „Człowiek i Środowisko”, 3, 145-151. [In Polish]

Lewandowski, K. (2004). Mięczaki (Mollusca) w dorzeczach Wisły i Odry (Mollusks (Mollusca) in the basins of the Vistula and Odra). Biuletyn Monitoringu Przyrody, 1, 5-9. [In Polish]

Lewin, I. (2014). Mollusc communities in lowland rivers and oxbow lakes in agricultural areas with anthropogenically elevated nutrient concentration. Folia Malacologica, 22(2), 87-159. http://dx.doi. org/10.12657/folmal.022.012

Piechocki, A. (1969). Mięczaki (Mollusca) rzeki Grabi i jej terenu zalewowego (Molluscs (Mollusca) of the Grabia River and its floodplain). Fragmenta Faunistica, 15, 111-197. 
Piechocki, A. (1972). Materiały do poznania mięczaków (Mollusca) rzeki Pasłęki (Materials to know the mollusks (Mollusca) of the Pasłęka River). Fragmenta Faunistica, 18, 121-139.

Piechocki, A. (1981). Współczesne i subfosylne mięczaki (Mollusca) Gór Świętokrzyskich (Contemporary and subfossil molluscs (Mollusca) of the Świętokrzyskie Mountains). Acta Universitatis Lodziensis, 177.

Piechocki, A. (1987). Mięczaki (Mollusca) rzek lessowego obrzeżenia Gór Świętokrzyskich (Mollusks (Mollusca) of the loess rivers edge of the Świętokrzyskie Mountains). Fragmenta Faunistica, 31(11), 169-181.

Piechocki, A. (1992). Mięczaki wodne (Mollusca aquatica) Roztocza (Freshwater molluscs (Mollusca aquatica) of the Roztocze Upland). Fragmenta Faunistica, 35(17), 285-299.

Piechocki, A. (1996). Aktualny stan poznania mięczaków słodkowodnych (Presentstate of knowledge on the Polish freshwater molluscan fauna). Acta Universitatis Lodziensis, Folia Limnologica, 6, 3-17. [In Polish]

Piechocki, A. (2008). Mollusca. Characteristic and checklist of species. In: W. Bogdanowicz, E. Chudzicka, I. Pilipiuk, E. Skibińska (eds.), Fauna of Poland. p. 365-425. Warszawa: Muzeum i Instytut Zoologii PAN.

Piechocki, A., Dyduch-Falniowska, A. (1993). Mięczaki (Mollusca), Małże (Bivalvia). Fauna Słodkowodna Polski (Molluscs (Mollusca), Mussels (Bivalvia). Freshwater fauna of Poland). Warszawa-Poznań: PWN. [In Polish]

Piechocki, A., Łuczak, C. (1989). Sphaeriidae (Bivalvia, Eulamellibranchia) górnego i środkowego biegu Wieprza (Sphaeriidae (Bivalvia, Eulamellibranchia) in the upper and middle reaches of the Wieprz). Przeglad Zoologiczny, 33(4), 559-566. [In Polish]

Piechocki, A., Szlauer-Łukaszewska, A. (2013). Molluscs of the middle and lower Odra: the role of the river in the expansion of alien species in Poland. Folia Malacologica, 21, 73-86. http://dx.doi. org/10.12657/folmal.021.008

Piechocki, A., Wawrzyniak-Wydrowska, B. (2016). Guide to Freshwater and Marine Mollusca of Poland. Poznań: Bogucki Wydawnictwo Naukowe.

Podbielkowski, Z., Tomaszewicz, H. (1996). Zarys hydrobotaniki (Outline of hydrobotany). Warszawa: Wydawnictwo Naukowe PWN. [In Polish]

Raczyńska, M. (1999). Zróżnicowanie struktury fauny bezkręgowej pod wplywem warunków biotopu rzeki Tywy (Diversification of the structure of invertebrate fauna under the influence of the biotope of the Tywa River). Praca doktorska. Szczecin: Uniwersytet Szczeciński. [In Polish]

RozporządzenieMinistra Środowiska $z$ dn. 21 lipca 2016 r. w sprawie sposobu klasyfikacji stanu jednolitych części wód powierzchniowych oraz środowiskowych norm jakości dla substancji priorytetowych (Dz. U. z 2016., Poz. 1187) (Regulation of the Minister of the Environment of July 21, 2016 on the method of classification of the state of surface water bodies and environmental quality standards for priority substances (Journal of Laws of 2016, item 1187).

Stadničenko, A.P. (1984). Molljuski, perlivnycebi, kul'kavi (Unionidae, Cycladidae). Fauna Ukraïni, 29. Kyïv. [In Ukrainian]

Wiśniewski, R., Kajak, Z., Bownik-Dylińska, L., Ejsmont-Karabin, J., Prejs, K., Spodniewska, I., Węgleńs$\mathrm{ka}, \mathrm{T}$. (1985). The effect of impoundments on the quality of water and biocoenosis in the lowland streams Rawka and Skierniewka. Ekologia Polska, 33, 511-536.

Zając, K. (2004). Unio crassus Philipsson, 1788. In: Z. Głowaciński, J. Nowacki (eds.), Polska czerwona księga zwierząt. Bezkregowce (Polish Red Data Book of Animals. Invertebrates). p. 353-355. Kraków-Poznań: Institute of Nature Conservation PAS and August Cieszkowski Agricultural University of Poznań. 
In 2016, the species composition and the structure of the dominance of molluscs in the Muchawka River (left-bank tributary of the Liwiec River) were assessed. The occurrence of 19 species of molluscs were recorded, including 11 species of snails and 8 species of mussels. The eudominant was Pisidium casertanum, which, only in the last two sites, constituted $43.1 \%$ of all molluscs. Two other species of molluscs from the Sphaeriidae family were also eudominants - Pisidium subtruncatum (22.8\%) and Sphaerium corneum (10.3\%). Snails were most frequently represented by the dominant Bithynia tentaculata, constituting $5.4 \%$ of all molluscs, and the subdominant Bathyomphalus contortus at $2.8 \%$. Sixteen years after the first malacological analysis, an increase in species richness and differences in the dominance of molluscs were found in the Muchawka River. Clams from the Sphaeriidae family invariably dominated but with a different species composition. The disappearance of the protected Anodonta cygnea and Sphaerium rivicola has been noted, and the occurrence of the protected Unio crassus has also been noted.

Key words: lowland river, molluscs, the Muchawka River

Received: [2020.07.29]

Accepted: [2020.09.24]

\section{Zmiany malakofauny w małej rzece nizinnej wschodniej Polski Streszczenie}

W 2016 roku dokonano oceny składu gatunkowego oraz struktury dominacji mięczaków rzeki Muchawki (lewobrzeżny dopływ Liwca). Odnotowano występowanie 19 gatunków mięczaków, a w tym 11 gatunków ślimaków i 8 gatunków małży. Eudominantem był małż Pisidium casertanum, który występując tylko na dwóch stanowiskach stanowił 43,1\% wszystkich mięczaków. Eudominantami były także dwa inne gatunki małży z rodziny Sphaeriidae - Pisidium subtruncatum (22,8\%) i Sphaerium corneum (10,3\%). Ślimaki najliczniej reprezentował dominant Bithynia tentaculata, stanowiąc 5,4\% wszystkich mięczaków oraz subdominant Bathyomphalus contortus - 2,8\%. Po szesnastu latach od pierwszej analizy malakologicznej w rzece Muchawka stwierdzono wzrost bogactwa gatunkowego oraz różnice w dominacji mięczaków. Niezmiennie dominowały małże z rodziny Sphaeriidae, ale przy innym składzie gatunkowym. Odnotowano zanik chronionej Anodonta cygnea i Sphaerium rivicola, a pojawienie się również chronionej Unio crassus.

Słowa kluczowe: rzeka nizinna, mięczaki, rzeka Muchawka

\section{Information on the authors}

Beata Jakubik https://orcid.org/0000-0002-1367-2805

Ecology of molluscs in various types of aquatic habitats, studies on life strategies of molluscs in response to different habitat conditions using family Viviparidae as an example.

\section{Krzysztof Lewandowski}

He is a professor emeritus of the Siedlce University of Natural Sciences and Humanities). Ecology of freshwater molluscs with special focus on abundant species (like e.g. zebra mussel Dreissena polymorpha, bivalves of the family Unionidae, the river snail Viviparus viviparus), that play an important role in the functioning of freshwater ecosystems; lake eutrophication and protection.

\section{Aleksandra Biernat}

Graduate student of the Institute of Biology, Siedlce University of Natural Sciences and Humanities. 